\title{
EFFECT OF STIMULATION OF LOCUS COERULEUS ON THE EVOKED POTENTIAL IN THE AMYGDALA IN RATS
}

\author{
Ryozo OISHI*, Shigenori WATANABE, Kenji OHMORI**, \\ Shigenobu SHIBATA and Showa UEKI \\ Department of Pharmacology, Faculty of Pharmaceutical Sciences, \\ Kyushu University, Fukuoka 812, Japan
}

Accepted August 16, 1978

\begin{abstract}
Effects of stimulation of the locus coeruleus (LC) on evoked potential in the medial amygdala clicited by stimulation of the olfactory bulb (OB-AME potential) were studied in gallamine-immobilized rats. The amplitude of the OB-AME potential was inhibited $27.5 \%$ by the conditioning stimulation of LC delivered $30 \mathrm{msec}$ before the test stimulation. The inhibitory effect of $\mathbf{L C}$ was reduced by propranolol $5 \mathrm{mg} / \mathrm{kg}$ i.p., but not by phentolamine $10 \mathrm{mg} / \mathrm{kg}$ i.p.. This effect was also reduced by tetrabenazine $10 \mathrm{mg} / \mathrm{kg}$ i.p.. Methamphetamine $5 \mathrm{mg} / \mathrm{kg}$ i.p. produced considerable potentiation of the LC inhibitory effect and a reduction of the OB-AME potential itself. These results suggest that the LC plays an inhibitory role in the clectrical activity of the medial amygdala.
\end{abstract}

The amygdala, particularly the medial anygdala plays an important role in regulating mouse-killing behavior (muricide) of the rat $(1,2)$. Leaf et al. (3) postulated that the noradrenergic system in the amygdala played an inhibitory role in the control of muricide, since noradrenaline administered directly into the amygdala inhibited muricide to some degree in most killer rats. Histofluorescence (4), biochemical (5) and autoradiographic studies $(6,7)$ have demonstrated that the noradrenergic innervation of the amygdala originates from the nucleus locus coeruleus (LC). In a previous report (8), we found that electrical lesions of the dorsal noradrenergic bundlc arising from LC greatly increased the incidence of muricide in olfactory bulbectomized cats. These results indicate that the dorsal noradrenergic bundle system modifies amygdaloid function.

There is much electrophysiological evidence that the LC has an inhibitory influence on numerous areas of the brain. Hoffer et al. (9) found that discrete stimulation of LC decreased the spontaneous discharge rate of cerebellar Purkinje cells through noradrenalinemediated mechanism. Similar inhibitory effects of LC stimulation on hippocampal pyramidal cells (10), relay neurons of the spinal trigeminal nucleus (11) and the transcallosal potential in cerebral cortex (12) have also been found. However, electrophysiological evidence for the role of LC in modulating the amygdaloid activity has apparently not been reported.

* Present address: Department of Pharmacology, Faculty of Medicine, Kyushu University, Fukuoka 812, Japan.

** Present address: Pharmaceutical Research Laboratory, Kyowa Hakko Kogyo Co. Ltd., Shizuoka 411, Japan. 
The present experiments were designed to clarify this point by studying the electrical activity of the amygdala elicited by stimulation of the olfactory bulb (OB).

\section{MATERIALS AND METHODS}

Twenty-two male Wistar rats weighing 300-350 g, supplied by Kyushu Laboratory Animals Co. were used. Animals were immobilized with gallamine triethiodide $(20 \mathrm{mg} / \mathrm{kg}$, i.p.) and artificially ventilated via an end tracheal cannula. The animals were then placed on a stereotaxic instrument, and $0.5 \%$ lidocaine was sprayed on all wound edges and gallamine triethiodide supplementation was used when necessary. For the test stimulation of $O B$, after a suitable hole was made in the skull just above the OB, the dura was cut and a bipolar clcctrode, made of stainless steel wire of $0.2 \mathrm{~mm}$ in diameter, insulated except for the tip, set $0.5 \mathrm{~mm}$ apart, was inserted $4 \mathrm{~mm}$ deep from the skull at an angle of $70^{\circ}$ down to the OB. According to the stereotaxic coordinates of König and Klippel (13) similar electrodes were inserted into the ipsilateral nucleus amygdaloideus medialis (AME) (A: 5.0, L: 3.3, $\mathrm{H}$ : -3.5) and LC (P: 1.5, L: 1.2, ventral 7.0 deep from the skull) in order to record the evoked potentials and supply the conditioning stimulation. All clectrodes were fixed with dental cement. Both $\mathrm{OB}$ and $\mathrm{LC}$ were stimulated with a square pulse of $0.5 \mathrm{msec}$ in duration and 5-10 V or 10-20 V in intensity, respectively, using a stimulator (MSE 40, Nihon Kohden). As a standard procedure, a train of 15 stimuli was delivered. The pulse interval was $3 \mathrm{sec}$. For the control of the potential recorded from AME elicited by OB stimulation (OB-AME potential), the conditioning stimulus was omitted. In order to study the effect of LC stimulation on OB-AME potential, the test pulse was preceded by a conditioning stimulus and the conditioning-test interval (C-T interval) was varied.

Each OB-AME potential was monitored on an oscilloscope ( $\mathrm{VC} 7$, Nihon Kohden) and at the same time, 15 potentials with or without LC conditioning stimuli were electronically averaged (Mediac, Sanei Sokki) and the averaged potential was plotted on a X-Y recorder. The amplitudes of OB-AME potentials were measured from the baseline to the peak of the major negative wave.

In order to better characterize the influence of LC on the potential, the effects of selected drugs were studied. The effects of the following drugs, administered intraperitoneally, were examined; phentolamine mesylate $10 \mathrm{mg} / \mathrm{kg}$ (Regitine, CIBA-GEIGY), propranolol hydrochloride $5 \mathrm{mg} / \mathrm{kg}$ (Inderal, Sumitomo), methamphetamine $5 \mathrm{mg} / \mathrm{kg}$ (Philopon, Dainippon) and tetrabenazine $10 \mathrm{mg} / \mathrm{kg}$ (Takeda). Methamphetamine hydrochloride was dissolved in $0.9 \%$ saline solution and tetrabenazine was suspended in a $0.5 \%$ carboxymethyl cellulose solution.

The location of inserted electrodes was verificd in cvery expcriment as follows: after removal of the electrodes, the brains were removed and fixed in a $10 \%$ formalin solution for several days. The positions of the electrode tips were determined microscopically on cresyl violet stained $50 \mu$ frozen sections. If the electrodes were not located in proper positions, the results from these rats were omitted for data analysis. Fig. 1 shows typical representative sections for the positions of electrodes in AME and LC. 


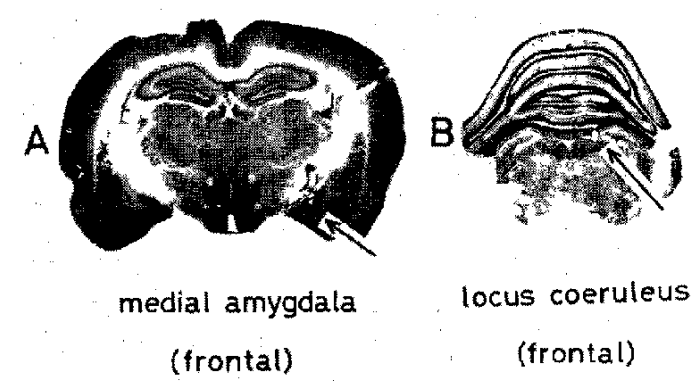

FIG. 1. Representative sections showing the sites of electrodes in the medial amygdala (A) and the locus coeruleus (B). Each section was stained with cresyl violet.

The statistical significance of the data obtained was assessed using the two-tailed Student"s $t$-test.

\section{RESULTS}

Effect of conditioning stimulation of LC on the $O B-A M E$ potsitial

Fig. 2 shows the effect of conditioning stimulation of LC $\mathrm{cn}$ the OB-AME potential. The OB-AME potential consists of two components: the first positive component and second negative one with peak latencies of 5 and $30 \mathrm{msec}$, respectively (Fig. 2, A). The conditioning stimulation of LC produced a significant decrease in amplitude of the second negative component, whereas it did not have any effect on the first positive one (Fig. 2, B). Inhibition of the second component was $27.5 \perp 7.6 \%$ (mean $\perp$ S.D., $\mathbf{n}-22$ ). No changes in the latencies of two components were observed.

Fig. 3 shows the effects of varying C-T intervals on the OB-AME potential. In the majority of the cases, the most effective inhibition of OB-AME potential was observed when the C-T interval was $30-40 \mathrm{msec}$. When C-T interval was $100 \mathrm{msec}$, the inhibitory effect was decreased (Fig. 3, C); no effect was observed when it was $200 \mathrm{msec}$ (Fig. 3, D). The LC stimulation per se caused a small distortion of the baseline which was limited to the
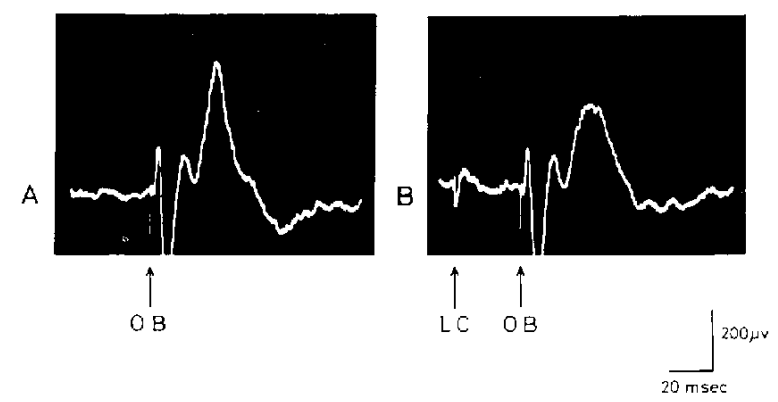

FIG. 2. Effect of conditioning stimulation of the locus coeruleus on the evoked potential in the medial amygdala elicited by the stimulation of the olfactory bulb. A: the evoked potential without conditioning stimulation, $B$ : the evoked potential with conditioning stimulation $30 \mathrm{msec}$ prior to the test simulation. 


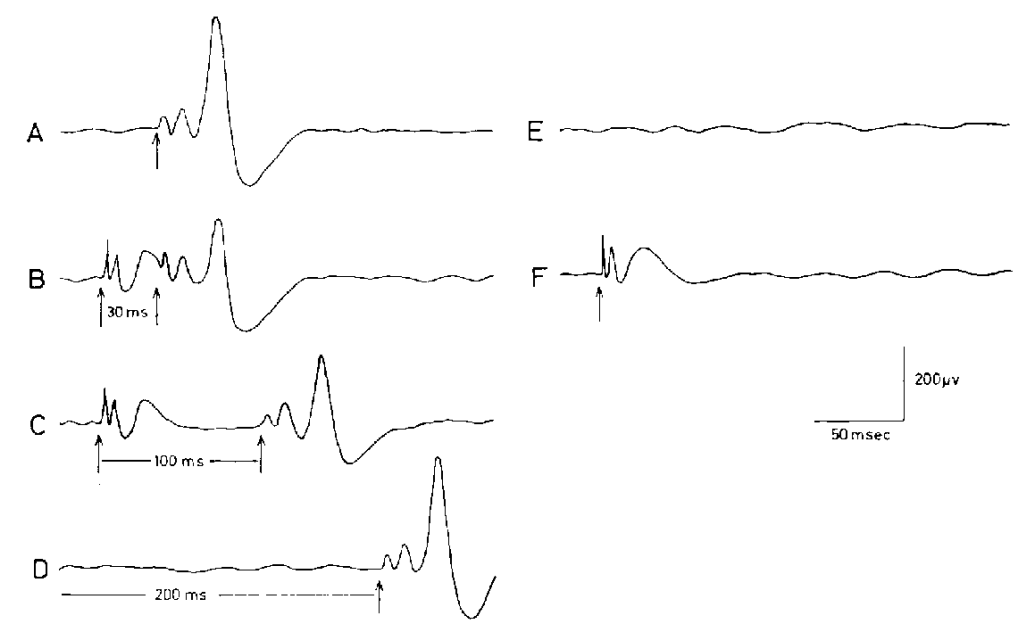

FIG. 3. Effects of conditioning stimulation of the locus coeruleus on the evoked potential in the medial amygdala elicited by the stimulation of the olfactory bulb are illustrated at various C-T intervals. A: the evoked potential without conditioning stimulation. $\mathrm{B}, \mathrm{C}$ and $\mathrm{D}$ : the evoked potentials with 30,100 and 200 msec $\mathrm{C}-\mathrm{T}$ intervals, respectively. $\mathrm{E}$ : the background activities in the medial amygdala. $F$ : the evoked potential elicited by only conditioning stimulation of the locus coeruleus. In each potential 15 responses were averaged.

first $50 \mathrm{msec}$ (Fig. 3, F). The test stimulus was delivered $30 \mathrm{msec}$ after the conditioning stimulus so that the response with the latency of $30 \mathrm{msec}$ after test stimulation fell outside the distorted region. Thus, 30 msec C-T interval was used throughout following pharmacological study.

\section{Effects of drugs on the $L C$ inhibitory effect on $O B-A M E$ potential}

Table 1 shows the effects of selected drugs on the LC inhibitory effect on the OB-AME potential. No significant changes in the OB-AME potential with or without LC conditioning stimulation were observed for as long as $120 \mathrm{~min}$ after the administration of a $0.9 \%$ saline solution, and the LC inhibitory effect was not changed either.

The amplitude of OB-AME potential itself and the LC inhibitory effect on the OB-AME potential were slightly reduced 30 min after intraperitoneal administration of phentolamine $10 \mathrm{mg} / \mathrm{kg}$. However, these effects of phentolamine were not significant statistically.

Administration of propranolol $5 \mathrm{mg} / \mathrm{kg}$ i.p. did not cause a significant change in the amplitude of OB-AME potential itself, but markedly reduced the LC inhibitory effect. The percentages of reduction were 53.7 and $44.2 \%$ at 15 and 30 min after the drug administration respectively. The effect of propranolol was partially reversed $60 \mathrm{~min}$ later.

Methamphetamine $5 \mathrm{mg} / \mathrm{kg}$ i.p. decreased the amplitude of OB-AME potentials both with and without LC conditioning stimulation, however the decrease in amplitude with conditioning stimulation was greater than that without conditioning stimulation. This result suggests that the $\mathrm{LC}$ inhibitory effect is potentiated by methamphetamine.

Tetrabenazine $10 \mathrm{mg} / \mathrm{kg}$ i.p. gradually increased the amplitude of the OB-AME potentials both with and without LC conditioning stimulation and the increase of the former 
TABLE 1. Effects of drugs on the inhibition by stimulation of the locus coeruleus on the evoked potential in the medial amygdala elicited by olfactory bulb stimulation

\begin{tabular}{|c|c|c|c|}
\hline & $\begin{array}{l}\text { Without } \\
\text { conditionings }\end{array}$ & $\begin{array}{l}\text { With LC } \\
\text { conditionings }\end{array}$ & $\begin{array}{l}\text { Change in LC } \\
\text { inhibitory effectss }\end{array}$ \\
\hline \multicolumn{4}{|l|}{ Saline $(n=5)$} \\
\hline Before treatment & 100 & $76.9=2.7$ & \\
\hline $15 \min$ & $100.1 \div 3.3$ & $76.6 \pm 3.7$ & $-4.4 \div 6.5$ \\
\hline $30 \mathrm{~min}$ & $103.7 ! 4.5$ & $80.4 \div 4.7$ & $-1.5=9.0$ \\
\hline $60 \mathrm{~min}$ & $100.6 \pm 2.3$ & $77.7 \pm 3.5$ & $+0.1 \pm 8.6$ \\
\hline $120 \mathrm{~min}$ & $102.9+3.4$ & $79.9+3.6$ & $-0.2+6.5$ \\
\hline \multicolumn{4}{|c|}{ Phentolamine $10 \mathrm{mg} / \mathrm{kg}$ i.p. (n $\cdots 5)$} \\
\hline Before treatment & 100 & $72.8 \pm 1.9$ & \\
\hline $30 \mathrm{~min}$ & $90.4+1$ - 5.9 & $68.8 \pm 3.4$ & $-13.4 \pm 6.8$ \\
\hline $60 \mathrm{~min}$ & $92.9 \div 4.9$ & $69.8+6.9$ & $+3.0 \pm 18.3$ \\
\hline \multicolumn{4}{|c|}{ Propranolol $5 \mathrm{mg} / \mathrm{kg}$ i.p. $(n=6)$} \\
\hline Before treatment & 100 & 69.51 .2 .7 & \\
\hline $15 \mathrm{~min}$ & $93.4-3.6$ & $80.1+3.4$ & $-53.7 .8 .7^{* * *}$ \\
\hline $30 \mathrm{~min}$ & $92.5-4.2$ & $76.7 \pm 5.9$ & $-44.2+13.8^{*}$ \\
\hline $60 \mathrm{~min}$ & $94.5-3.7$ & $70.4+4.9$ & $-12.8 \_16.2$ \\
\hline \multicolumn{4}{|c|}{ Methamphetamine $5 \mathrm{mg} / \mathrm{kg}$ i.p. $(n=4)$} \\
\hline Before treatment & 100 & $74.7 .+5.5$ & \\
\hline $15 \mathrm{~min}$ & $64.9 \ldots 10.8^{*}$ & $35.3\lrcorner .8 .1^{* *}$ & $102.0 \div 45.4^{*}$ \\
\hline $30 \mathrm{~min}$ & $66.7-8.3^{* *}$ & $51.0 \pm 4.0^{* *}$ & $-20.9 \pm 17.7$ \\
\hline $60 \mathrm{~min}$ & $73.8+4.4^{* * *}$ & $56.2+2.8^{* *}$ & $+4.6+25.4$ \\
\hline \multicolumn{4}{|c|}{ Tetrabenazine $10 \mathrm{mg}$ kg i.p. $(n-4)$} \\
\hline Before treatment & 100 & $660--3.9$ & \\
\hline $30 \mathrm{~min}$ & $106.3=3.6$ & $81.8 \ldots 3.0$ & $-32.0-6.9 *$ \\
\hline $60 \mathrm{~min}$ & $114.0-49^{*}$ & $85.5-6.2$ & $-28.6-7.8^{*}$ \\
\hline $120 \mathrm{~min}$ & $117.8 \div 2.6^{*}$ & $94.3=5.9$ & $-41.7 ! 10.3^{* *}$ \\
\hline
\end{tabular}

$\$$ Each value indicates the percentage of the amplitude to that without conditioning stimulation of the locus coeruleus before drug administration. $\$ \$$ Each value indicates the percent change in the inhibitory effect of locus coeruleus stimulation to that before drug administration. Each value is shown as mean \pm S.E.M. $\mathrm{n}$ : Number of rats. ${ }^{*} \mathrm{p}<0.05 ;{ }^{* *} p<0.01 ;{ }^{* *} \mathrm{p}<0.001$ significant difference vs those of saline treatment.

was greater than that of the latter, indicating that tetrabenazine suppressed the LC inhibitory effect. There were significant differences between tetrabenazine and saline treated groups at 30,60 and 120 min after administration.

\section{DISCUSSION}

Electrophysiological studies on the role of noradrenergic neurons derived from LC have been directed to several neurons such as cerebellar Purkinje cells (9), hippocampal pyramidal cells (10) and cells in the spinal trigeminal nucleus (11), and cvidence was provided that activation of LC inhibited these neurons by a noradrenaline-mediated mechanism, involving $\beta$-receptor. In the present experiments, we demonstrated that conditioning 
stimulation of LC inhibited the amplitude of the OB-AME potential. Although there is no direct evidence for a synaptic connection between LC and AME, Ross and Reis (5) reported that dopamine- $\beta$-hydroxylase activity in the amygdala-entorhinal cortex was significantly reduced following electrolytic lesions of LC. Moreover, several autoradiographic studies $(6,7,14)$ have indicated that the axons derived from $\mathrm{LC}$ give off branches to the amygdala. Therefore, we postulate that LC stimulation inhibits the electrical activity in AME by way of noradrenergic axons from LC. This notion receives further support from the results of pharmacological test in the present study.

Phentolamine, an $\alpha$-receptor blocking agent, produced no significant changes on the LC inhibitory effect. The lack of effect is not due to inaccessibility of the drug to the central nervous system, since it has been reported that phentolamine crosses the blood brain barrier and causes central actions (15). Therefore, it is unlikely that the LC inhibitory effect is mediated by $\alpha$-receptor. On the other hand, propranolol, a $\beta$-receptor blocking agent, showed a significant reduction of the LC inhibitory effect concomitant with a slight decrease in amplitude of the OB-AME potential itself. This decrease in amplitude of the OB-AME potential may be ascribed to a direct action of propranolol on nerve membrane since it is well known that propranolol has a nonspecific membrane stabilizing action like that seen with local anesthetics (16). However the selective action of propranolol on the LC inhibitory effect suggests that the effect of propranolol could be due to its $\beta$-receptor blocking action rather than nonspecific local anesthetic action. This notion is strengthened by the observation that LC inhibition in hippocampal pyramidal cells was reduced by MJ-1999 (10), a selective $\beta$-receptor blocking agent, which has less nonspecific membrane stabilizing action (17).

Methamphetamine exhibits an effect similar to that of amphetamine, which releases noradrenaline from the terminal of noradrenergic fiber in the brain (18). It has also been indicated that activation of reticular-arousal-system neurons by locally applied amphetamine is prevented by agents that cause the depletion of noradrenaline but not dopamine in the brain (19). Moreover, Ritter and Stein (20) reported that self-stimulation of LC, for which the activation of noradrenergic neurons were essential, was facilitated by low doses of amphetamine. These findings may support the notion that the considerable facilitation of the LC inhibitory effect on OB-AME potential by methamphetamine was due to its noradrenaline releasing action in the nerve terminals. This notion is further supported by the fact that the $L C$ inhibitory effect on OB-AME potential was reduced by tetrabenazine which is a rapid depletor of noradrenaline. The reduction in amplitude of the OB-AME potential itself by methamphetamine may be due to the facilitation of spontaneous release of noradrenaline. However, the possibility of a direct stimulating action of methamphetamine on noradrenergic receptors in AME cannot be excluded. The gradual increase in the amplitude of OB-AME potential by tetrabenazine may be due to a lesser degree of the LC inhibitory effect as a result of the depletion of noradrenaline in the nerve terminals.

The data obtained in the present pharmacological studies suggest that the LC inhibitory effect on the OB-AME potential is mediated by noradrenergic mechanisms, particularly by 
activating $\beta$-receptors.

\section{REFERENCES}

1) Vergines, M. and KarLi, P.: Déclenchement du comportement d'agression interspécifique Rat-Souris par ablation bilatérale des bulbes olfactifs. Action de l'hydroxyzine sur cette agressivité provoquée. Comp. Rend. Soc. Biol. 157, 1061-1063 (1963)

2) Karli, P., Verg.jes, M., Ectanchfr, F., Scimitt, P. and Cinurand, J.P.; Role of the amygdala in the control of "mouse-killing" behavior in the rat. Advances in Behavioral Biology, Edited by Elet Theriou, B.E., Vol. 2, p. 553-580, Plenum Press, New York and London (1972)

3) LeAF, R.C., LFRner, L. AND HOROVITZ, J,P.: The role of the amygdala in the pharmacological and endocrinological manipulation of aggression. Aggressive Behaviour, Edited by Garattini, S. And Sigg, E.B., p. 120-131, Excerpta Medica Foundation, Amsterdam (1969)

4) Lindvall, O. AND BJörki.uNd, A.: The organization of the ascending catccholamine ncuron systems in the rat brain. Acta physiol. scand. Suppl. 412, 1-48 (1974)

5) Ross, R.A. AND Reis, D.J.: Effects of lesions of locus coeruleus on regional distribution of dopamine- $\beta$-hydroxylase activity in rat brain. Brain Res. 73, 161-166 (1974)

6) JONES, B.E. AND MOORE, R.Y.: Ascending projections of the locus coeruleus in the rat. II. Autoradiographic study. Brain Res. 127, 23-53 (1977)

7) Slgal, M., Pickel, V. and Bloom, F.E.: The projections of the nucleus locus coeruleus: an autoradiographic study. Life Sci. 13, 817-821 (1973)

8) OISHI, R. AND UeKI, S.: Facilitation of muricide by dorsal norepinephrine bundle lesions jin olfactory bulbectomized rat. Pharmacol. Biochem. Behav. 8, 133-136 (1978)

9) Hofffr, B.J., Siggins, G.R., Oliyer, A.P. And Bloom, F.E.: Activation of the pathway from locus cocruleus to rat cerebellar Purkinje neurons: Pharmacological evidence of noradrenergic central inhibition. J. Pharmacol. exp. Ther. 184, 553-569 (1973)

10) Segal, M. and Bloom, F.E.: The action of norepincphrine in the rat hippocampus. II. Activation of the input pathway. Brain Res. 72, 99-114 (1974)

11) Sasa, M., Munekryo, K., Ikeda, H. and Takaori, S.: Noradrenaline-mediated inhibition by locus coeruleus of spinal trigeminal neuron. Brain Res. 80, 443-460 (1974)

12) Austin, J.H. AND TAKaORI, S.: Studies on connections between locus cocrulcus and cerebral cortex. Japan. J. Phamacol. 26, 145-160 (1976)

13) König, J.F.R. ANd Klippel, R.A.: The Rat Brait, A Stereotaxic Atlas of the Forebrain and Lower Parts of the Brain Stem, Williams and Wilkins, Battimore, Md. (1963)

14) Jones, B.E., Halaris, A.E., Mcit.hany, N. and MoOre, R.Y.: Ascending projcctions of the locus cocruleus in the rat. I. Axonal transport in central noradrenaline neurons. Brain Res. 127, 1-2I (1977)

15) Blikgmann, F., Catane, R. AND KorCZYN, A.D.: Central actions of regitine (phentolamine) on blood pressure. Archs int. Pharmacodyn. Ther. 168, 278-287 (1967)

16) BARRetT, A.M.: A comparison of the effects of (-I)-propranolol and ( 1 )-propranolol in anesthetized dogs; $\beta$-receptor blocking and hacmodynamic action. J. Pharm. Pharmacol. 21, 241-247 (1969)

17) Lish, P.M., Weikel, R. And DUnGian, W.K.: Pharmacological and Loxicological propertics of two new $\beta$-adrenergic receptor antagonists. J. Pharmacol. exp. Ther. 149, 161-173 (1965)

18) Glowinski, J. And Axelrod, J.: Effect of drugs on the uptake, release, and metabolism of $\mathrm{H}^{3}$-norepinephrine in the rat brain. J. Pharmacol. cxp. Ther. 149, 43-49 (1965)

19) Bonkes, R.J., BRadley, P.B. ANd CANDy, J.M.: A neuronal basis for the alerting action of (†)-amphetamine. Brit. J. Pharmacol. 45, $391-403$ (1972)

20) Ritter, S. AND Stein, L.: Self-stimulation of noradrenergic cell group (A6) in locus cocruleus of rats. J. comp. physiol. Psychol. 85, 443-452 (1973) 